IFN Working Paper No. 1185, 2017

\title{
Deregulation and Regional Specialization: Evidence from Canadian Agriculture
}

Colin A. Carter and Shon Ferguson 


\title{
Deregulation and Regional Specialization: Evidence from Canadian Agriculture*
}

\author{
Colin A. Carter ${ }^{\dagger}$ \\ Shon M. Ferguson ${ }^{*}$ \\ September 2017
}

\begin{abstract}
For about seventy years, the Canadian Wheat Board (CWB) was one of the world's largest export "single desk" state traders in agriculture, until it was deregulated in 2012 and stripped of its marketing powers. One of the main crops controlled by the CWB was barley. We estimate the impact of the removal of the CWB's single desk on the spatial pattern of malting barley production in Western Canada. We find that deregulation encouraged growers located closer to malt barley plants to increase production relative to growers located further from the plants. Additionally, malting barley production shifted to regions with more of a natural advantage arising from climatic conditions. This change in cropping patterns after deregulation can be explained by efficiency gains, combined with transportation and handling cost savings.
\end{abstract}

JEL Classification Codes: L43, Q17, Q18, R12, R14

Keywords: state trading, deregulation, agricultural regulation, trade costs, comparative advantage

\footnotetext{
* Financial assistance from the Jan Wallander and Tom Hedelius Foundation and the Marianne and the Marcus Wallenberg Foundation is gratefully acknowledged.

${ }^{\dagger}$ Dept. of Agricultural and Resource Economics and Giannini Foundation of Agricultural Economics, UC Davis, Davis CA, USA

* Research Institute of Industrial Economics (IFN), Stockholm, Sweden. Corresponding author. Email: shon.ferguson@ifn.se
} 
State Trading Enterprises (STEs) are prevalent in many sectors, especially agriculture, and the effects of deregulating STEs are of interest because it has been difficult to measure their true market impact while they are operating (Horlick and Mowry, 1998). A large STE, with annual sales between CAD $\$ 4$ to $\$ 8$ billion (CWB 2012), the government-operated Canadian Wheat Board (CWB) was deregulated in 2012. We evaluate the impact of the removal of the CWB's statutory powers on the production of malting barley ${ }^{1}$ in the prairie provinces of Alberta, Saskatchewan and Manitoba. ${ }^{2}$ A natural experiment, this major institutional change meant that growers on the Canadian Prairies were no longer required to sell their malting barley to the government. Instead, growers could now deal directly with buyers through negotiations on prices and other marketing arrangements such as delivery methods, quality standards, storage costs, and timing of delivery.

Prior to 2012, the CWB purchased and sold all Canadian barley destined for malt (a major input used to brew beer) and prairie growers received the same "pooled" crop year price, for a given quality, corrected for transportation costs. The CWB had monopsony buying power over the growers, and at the same time it was a monopoly seller of malting barley grown on the Canadian prairies. Through its role as "single buyer", the CWB controlled how much malting barley was sold by Canadian growers into domestic and export markets in any given crop year. Further, the CWB effectively controlled the amount of malt that could be sold by each processor in the domestic and foreign markets they served. In effect, the CWB controlled the maltsters price-cost margins and their volume of sales. And the maltsters supported the CWB single desk regime, even though it was a monopoly they were buying from.

The pooled price was adjusted for transportation costs, and reflected a weighted average rate based on the market destination of the entire malt barley crop (domestically, the U.S. and overseas). Freight charges set by the CWB at a given location on the prairies correlated strongly with the distance from that delivery point to seaport. This meant that the farm gate price of malt barley received by growers located beside a local malt plant did not reflect its proximity to the plant. The pooling concept distorted the incentive for farms close to malt plants to specialize in malt barley, which would have otherwise occurred given their locational advantage. The purpose

\footnotetext{
${ }^{1}$ Malting barley is processed for malt, used in beer production. If barley is not selected for malting then it is sold into the lower priced feed barley market.

${ }^{2}$ In 2012 the CWB lost its statutory marketing rights for both barley and wheat. In this study we focus on the impacts of deregulation on the malting barley market. The CWB had a full monopoly on malting barley, while their monopoly powers on feed barley only applied to exports.
} 
of our paper is to evaluate whether the change in grower incentives after 2012 led to a change in the spatial pattern of malt barley production.

Using regression analysis, we employ a first-differencing methodology to analyze the role of proximity to a malting plant on the change in acres planted to malt barley varieties, comparing the 2008-11 period with 2013-16. We find that the removal of the CWB marketing power had a significant impact on the spatial distribution of malt barley production, with a shift towards production in areas geographically closer to malting plants. Furthermore, we find a shift in production to regions more climate friendly to the production of malting barley. This change in cropping patterns is robust to a variety of controls. The point estimates suggest that malt barley acreage expanded by between $11 \%$ and $21 \%$ for every $100 \mathrm{~km}$ closer a rural municipality (RM) is to the nearest malt barley plant, depending on the choice of specification.

This study contributes to a literature that analyzes the impact of government regulation on agriculture. Compared to a competitive benchmark, export STEs can theoretically distort both the domestic and international markets. However, theoretical conclusions regarding economic effects of specific STEs are difficult to establish because of their opaque nature of operation and the difficulty of ascertaining the specifics of their objective function (McCorriston and MacLaren 2013).

As a government agency, the CWB was not necessarily maximizing profits (Hoekman and Trachtman 2008). While the theoretical possibility of manipulating export markets existed, in practice the CWB was established for public-policy purposes, including income redistribution to achieve equity and to generate political support for the continuation of the agency's powers. This involved distorting market signals to growers through price and cost pooling. In fact, Carter, Loyns, and Berwald (1998) argued that most of the effects of the CWB were domestic (inefficiencies). In the case of the Australian Wheat Board (AWB), also now deregulated, McCorriston and MacLaren (2007) also found the main market impact was domestic. This paper is the first to our knowledge to study the domestic impacts of the restoration of market signals to growers in a STE post-regulated environment.

Our finding that STE deregulation leads to a greater geographic specialization in the production of malt barley relates directly to the Ricardian concept that free trade allows regions to specialize according to comparative advantage. Several studies have shown both theoretically and empirically that lower trade costs permit gains from specialization in agriculture (Donaldson 
2015, Costinot and Donaldson 2016 Donaldson and Hornbeck 2016, Cosar and Fajgelbaum 2016, Fajgelbaum and Redding 2017, Sotelo 2016). While these studies exploit the effects of infrastructure and policy changes in countries during their development phases, our analysis is unique in that we study the impact of a contemporary policy change in a developed country. Our work also contributes to a growing literature studying the misallocation of production due to domestic policy distortions, which has been shown to have large quantitative impacts on aggregate efficiency (Hsieh and Klenow 2009). Finally, our work contributes to previous literature studying the impact of policy distortions on agricultural specialization and production incentives (Peterson and Valluru 2000, Anderson et al. 2008).

\section{Malt Barley Marketing in Western Canada}

We now describe malting barley production and marketing before and after the CWB monopoly was eliminated.

\section{The malt barley market}

Grain and livestock production remain a large component of the provincial economies in Alberta, Saskatchewan and Manitoba. Barley is grown both for use as malt and for use as a feed for livestock. The variety of barley grown on each farm is determined by its intended end use, as maltsters have very specific requirements on the varieties they purchase. However, growing a barley variety deemed suitable for malt is not sufficient to guarantee acceptance as malt, as there are strict quality guidelines in terms of protein content, plumpness and other quality measures that must be met in order for a grower's barley to "go malting". The share of barley that is actually sold as malt barley is called the "selection rate". The selection rate varies from year to year, depending on supply-side factors such as weather, and also demand-side factors. The Canadian selection rate varied between $40 \%$ and $76 \%$ during the 2007/08 and 2015/16 period, depending on whether uninsured barley acres are included in the calculation.

Growing barley that meets malt quality criteria requires special weather conditions combined with careful management practices. ${ }^{3}$ Hot and dry conditions lead to protein content that is too high, and drought can adversely affect the plumpness of the kernels. Excessive rain harms quality, especially heavy rain in August, just prior to harvest. The weather-dependent

\footnotetext{
${ }^{3}$ Personal communication with Professor Aaron Beattie, Department of Plant Sciences and Crop Development Centre, University of Saskatchewan, April 4, 2017.
} 
nature of malt barley production means that there is an element of uncertainty facing growers in producing malt quality barley each year. Modern growers store their barley in special aeration bins in order to maintain malting quality prior to delivery to a malting plant.

There are four malt plants located on the Canadian prairies: Canada Malt (Calgary, AB), Rahr Malt (Alix, AB), Prairie Malt (Biggar, SK) and Malteurop (Winnipeg, MB). The malt barley plants are generally located in areas that are conducive to producing malt barley, but their geographic location is also affected by proximity to downstream brewers. Outside the prairies, Canada Malt also has malting plants in Montreal and Thunder Bay. The malt produced in the western Canadian plants is sold to local brewers or exported. Canadian malt exports totalled 616 thousand tonnes in 2016, with the U.S., Japan, Mexico and South Korea as the top destinations (UN Comtrade 2017). Just outside of Canada, Malteurop also has a malt plant in Great Falls, Montana, while Cargill and Anheuser-Busch have facilities near Fargo, North Dakota. Figure 1 shows the location of malt barley plants in Western Canada and on the U.S. Northern Great Plains.

\section{Marketing malt barley through the $C W B$}

Until August 2012, wheat and barley grown in the designated area of Western Canada (Manitoba, Saskatchewan, Alberta, and the Peace River region of British Columbia) for human consumption could only be sold via the CWB. In this case, grain companies accepted delivery, stored and handled the wheat and barley as agents of the CWB, using the same elevator facilities as for other "non-board" grains such as canola.

After harvest, a malting barley grower would send a barley sample to the Canadian Grain Commission to be graded. If the sample met the quality standards established by malt processors then the CWB could select part or all of the grower's malt barley crop for delivery, but it was not obliged to do so. As mentioned earlier, most malting barley was not accepted for malt and the pooling concept meant that the CWB did not discriminate on the basis of proximity to malting plants when determining which farms would receive the premium price associated with malt barley over feed barley. This issue of fairness meant that in many years most growers sold no more than a single railcar (approximately 80 tonnes) of malt barley.

A portion of the malt barley crop would be sold by the CWB to domestic maltsters, and the

rest would be sold by the CWB to maltsters in other countries. A grower who had some malting barley selected would receive the pooled CWB price for malt barley delivered within a "crop 
year" (August $1^{\text {st }}-$ July $31^{\text {st }}$ ). Growers would deliver their malt barley to one of many "elevators," a short-term local storage facility owned by a grain company and usually located along a rail line.

Price pooling meant that the price at the farm gate equalled the annual pooled price minus the cost of railway transportation from the grower's local elevator to seaport. The price a grower received for their malting barley at a particular location did not necessarily reflect the price paid by the malting plant that received the barley, adjusted for freight costs.

The CWB only called up malting barley from growers, as it was needed. As a result, growers were often required to store their malting barley on farm for several months and to dispose of any surplus to CWB requirements in the domestic feed market at a lower price. The CWB sold malting barley destined for three different markets: (a) the domestic malt market (about $20 \%$ of sales), (b) the foreign malt market (about $30 \%$ of sales), and (c) the foreign malting barley market (about $50 \%$ of sales). Growers could only access these markets by delivering malting barley to country elevators or processors at the behest of the CWB. Some domestic malting barley sales involved contracts between a specific grower and processor, ${ }^{4}$ but most growers did not have production contracts and each year they faced the risk that the CWB would not select their malting barley.

Essentially, therefore, most Canadian growers played in a lottery operated by the CWB. The lottery worked as follows. Growers were free to plant either feed barley varieties, which had higher yields, or malting varieties that were lower yielding but potentially more valuable per bushel. If a grower's malting barley met the quality standards, then the CWB may have selected the grower's malt barley crop for delivery, but there was no guarantee. Ex ante, therefore, each grower did not know whether his or her crop would be selected and was literally taking a gamble on the CWB's behaviour. ${ }^{5}$

\footnotetext{
${ }^{4}$ Some malting barley was grown under production contracts (typically signed between a maltster and a grower) but the majority of Canadian malting barley was grown without a contract and, either way, growers received the same malting barley pool price. Industry sources indicate that about $60 \%$ of malting barley sales to the domestic malt market, about $30 \%$ of all malting barley sales managed by the CWB, were procured through production contracts. Growers with these production contracts knew their malting barley would be selected for malt if it met quality standards. However, $70 \%$ of all malting barley purchases did not involve such contracts, and the CWB determined which growers were selected to deliver barley for malt and receive the malting barley pool price.

${ }^{5}$ Once a grower's malting barley had been selected for potential malt production, however, they faced another risk. They had no idea about when the "selected" barley will be "called forward" for delivery to the market. Since maltsters operated their plants year round, and did not carry barley inventories, some selected lots were not called forward from growers for several months after selection. The "selected" barley then had to meet the required quality
} 
The CWB's malting barley lottery encouraged growers to plant substantially more malting barley (and less feed barley) than would have occurred under a direct contract system. Under direct contracting, if an individual grower's malting barley crop does not meet minimum malting quality standards, then the crop is sold for feed. However, if the crop met the prescribed quality standards then it would be selected for malt.

The CWB placed no constraints on the area planted to malting barley varieties and so an average grower's probability of success - selling malting barley at the malting barley price - was roughly equal to the ratio of the quantity of barley selected for malt processing to total malting barley production. In making planting decisions about malting and feed barley, therefore, Canadian growers evaluated the trade-offs between expected yield differentials, expected price differentials, and the probability that they will be winners in the CWB's malting barley lottery (the expected selection rate). If the expected pay-off from malting barley exceeded the expected pay off from feed barley, individual risk neutral growers would expand the area planted to malting barley, lowering the selection rate. Thus, while the selection rate was exogenous to any individual grower's planting decision, it was endogenous to the planting decisions of the industry as a whole. As a result, relative to expected demand, Canadian growers planted a larger acreage to malting barley varieties than they would have under contracting. This was favourable for the maltsters because it meant that a lower proportion of malting barley production was sold for malt processing and they could choose the "cream" of the crop in terms of quality.

\section{Malt barley marketing after the CWB monopoly}

The CWB's authority to sell wheat and barley on behalf of growers officially ended on August $1^{\text {st }}, 2012$. Once growers were no longer compelled to sell to the CWB they could market their malt barley in the same way as they already marketed "non-board" grains such as canola. Growers began to contract directly with malting plants or sell to grain companies. When selling directly to malting plants, growers now typically contract part of their malt barley crop during the winter and spring months, specifying a delivered quantity and price. Grain companies purchase the majority of malt barley that is destined for export, mostly through the spot market.

criteria at the time of being "called forward." Growers ran the risk of sprout damage during months of storage or failing to meet germination requirements. It is not unheard of for a grower's barley to be selected and, then months later, to be rejected when called forward because it no longer met the maltster's quality specifications. 
In many ways, the Canadian system of malt barley pricing and marketing is now similar to that in the United States. In the U.S., malting barley is generally produced under contract, although some is sold on the spot market. Under a typical U.S. contract, a malting company agrees to accept all of a grower's output at a predetermined malting barley price as long as the barley meets the minimum malting quality standards defined in the contract. ${ }^{6}$ U.S. maltsters offer growers price premiums for malting barley (over feed barley prices) partly because malting barley varieties have lower yields and partly because of production risks that may lead to rejection of malting barley for malting purposes (Wilson, 2009).

\section{Efficiency and Distributional Impacts}

We posit that the end of the CWB single desk affected the price and cost of producing malt barley in several ways. First, it became more common for growers to deliver their crop directly to the malting plants by truck instead of delivering to a local elevator and incurring handling and elevation fees. The avoidance of handling and elevation fees would be passed on to growers to some extent, regardless of whether the farm was close or far from the malting plant. Second, the elimination of freight cost pooling reduced the net price received at farms furthest way from malt barley plants. Third, growers that were more adept at producing malt barley could contract their crop in advance and be guaranteed a market for their malt barley as long as their harvest met the quality criteria. The ability to contract reduced the marketing uncertainty associated with malt barley production, which enhanced the welfare of those growers focusing on malt barley.

\section{Empirical Methodology}

Our analysis takes the form of an OLS regression. We propose the following first-differenced specification for measuring the effect of the removal of the CWB monopoly on malting barley acreage in each census consolidated subdivision (CCS):

$$
\Delta \ln \left(\text { MaltBarley }_{i, t}=\alpha+\beta\left(\text { maltplant_dist } t_{i}\right)+M B d u m+A B d u m+\delta_{1} Z_{i}+\varepsilon_{i}\right.
$$

\footnotetext{
${ }^{6}$ If these standards are not met, then the grower may default on the contract without penalty and dispose of the barley in the feed market at a lower feed barley price. Alternatively, the contract may be re-negotiated and the barley purchased by the malt processor at a price discounted for quality.
} 
where $\Delta \ln (\text { MaltBarley })_{i, t}$ is the logged change in the average number of acres planted to malt barley varieties in Rural Municipality (RM) $i$, comparing the pre-reform years 2008-2011 and the post-reform years 2013-2016. maltplant_dist ${ }_{i}$ is the distance (in kilometres) from an RM to its nearest malt barley plant. $Z_{i}$ is a vector of time-constant controls such as distance to seaport and weather, which varies across RM locations.

The first-differencing process subsumes the RM fixed effects, which capture all time-constant factors that may influence the outcome variables. Adding distance to seaport and weather further controls for the possibility that distance to seaport or other underlying geographical factors influence the decision to grow barley for malt. We include July average temperatures and August precipitation as controls because hot summer temperatures and rain during the harvest can have adverse effects on quality.

Our main coefficient of interest is $\beta$, with the null hypothesis that $\beta=0$. We expect a negative sign for $\beta$ if barley production shifts toward RMs that are relatively close to malt barley plants after the end of the CWB single desk. The constant term $\alpha$ in this first-differenced specification picks up any changes in malt barley production that is due to factors that affect all locations identically, such as world malt barley prices or the introduction of new and improved malt barley varieties.

The size of the coefficient $\beta$ can be interpreted is a measure of the sensitivity of malt barley acreage to distance to the nearest plant. The coefficient $\beta$ indicates that malt barley acreage increases by $100 * \beta$ percent for every $1 \mathrm{~km}$ change in distance to the nearest malt barley plant. For example, consider two RMs located $50 \mathrm{~km}$ and $150 \mathrm{~km}$ away from the nearest plant. Given that the difference in proximity to the plant is $100 \mathrm{~km}$, the coefficient $\beta$ allows us to predict the closer RM will grow $100 * 100 * \beta$ percent more malt barley than the more distant RM. Our identification strategy allows us to tease out the spatially different impacts on malt barley production, but it does not capture the total impact of the policy since the total impact is confounded by other unobserved time-varying factors.

\section{Data and Descriptive Statistics}

We combine data on malt barley production and acreage from crop insurance records with data from the Census of Agriculture and data on climate and soil characteristics. This section 
explains the data sources and how they were combined. We also present some descriptive statistics.

\section{Crop Insurance Data}

The Canadian government does not collect data on malt versus feed barley production. However, growers are obliged to report the variety grown in each field when applying for crop insurance. We thus use data on the acreage and production of malt barley varieties collected from the three crop insurance agencies in Alberta, Saskatchewan and Manitoba. The variety data is per county in the case of Alberta and per rural municipality (RM) in the case of Saskatchewan and Manitoba. In total, we have data on over 400 finely detailed spatial units across the prairies.

Figure 2 illustrates that insured acreage of malt barley varieties has been fairly consistent over the period that we study, apart from the decline in Saskatchewan between 2008 and 2011. Alberta is the largest malt barley producer in most years, with an average acreage of 1.5 million. Saskatchewan is the next largest producer with acreage between 1 and 1.5 million. Manitoba is the smallest producer with annual production between 100 thousand to 400 thousand acres.

Figure 3 illustrates the share of total barley acreage (malt and feed) that is insured, combining the crop insurance data with annual production survey data available from Statistics Canada. The share of barley acreage that is insured is fairly consistent over time in Saskatchewan and Alberta, the two largest producers. Approximately $45 \%$ to $55 \%$ of barley acres are insured in Saskatchewan during the time period we study, while insurance participation is slightly higher in Alberta, averaging between $60 \%$ to $65 \%$. Manitoba has the highest insurance participation on average, although it is more volatile over time, ranging between $70 \%$ to $100 \%$.

We combine the crop insurance data with data on weather and soil quality, which is also available at the county or RM level. The weather data is from the University of East Anglia (Harris et al. 2014). We measure the distance of each county or RM from the nearest malt plants using GIS techniques. We also measure the distance from each RM to the nearest seaport (Vancouver or Thunder Bay), and use this as a proxy for the malt barley export basis.

\section{Malt barley supply and disposition}

The supply and disposition for malt barley in Western Canada for the period we study are presented in Table 1. Supply and disposition tables for malt barley have not been published by Statistics Canada since the 2007/08 crop year. The calculation of the selection rate hinges critically on the production data for malt barley varieties, and the lack of insurance participation 
on $100 \%$ of malt barley acreage makes this calculation imperfect. We calculate selection rates using the raw crop insurance data (which underestimates total production of malt barley varieties), and we adjust for uninsured acres using annual crop survey data for total barley acreage in each province (feed plus malt). One issue with this adjustment is that it assumes the crop insurance participation rate is identical for feed barley and malt barley, and if feed barley has systematically lower insurance participation than malt barley (which is likely the case since it is a low-value crop) then this conversion will overestimate malt barley acreage. The adjusted and unadjusted production values hence represent an upper and lower bound on actual production of malt barley. Overall, we find that the selection rate when adjusting for uninsured acres has fluctuated between 40 and 54 percent, while the unadjusted selection rate is more volatile, ranging between 52 and 76 percent.

We illustrate changes in malt barley acreage graphically in Figure 4. This map shows that after deregulation there was a distinct shift in malt barley acreage away from many RMs in eastern Saskatchewan and western Manitoba and towards Alberta, west-central Saskatchewan and eastern Manitoba. This pattern suggests that malt barley production moved towards the locations of the malt barley plants. At the same time, figure 4 suggests that malt barley production increased in Alberta in general, regardless of proximity to a malt barley plant.

\section{Main Results}

The main regression results are presented in Table 2. The dependent variable in all specifications is the 2008-11 versus 2013-16 average change in the log of malt barley acres in each RM. In column (1) we include only our variable of interest, the distance to the closest malting plant (maltplant_dist). In column (2) we add province-level dummy variables, which are crucial since crop insurance is administered separately within each province, and insurance participation for malt barley appears to vary systematically across provinces. $A B_{i}$ and $M B_{i}$ take a value of 1 if the RM is located in Alberta or Manitoba respectively and zero otherwise; Saskatchewan is the omitted province. Since our dependent variables are first-differenced, these dummies control for province specific variations in malt barley production that could be driven by any crossprovincial differences in agricultural policy. In column (3) we add long-run weather variable averages as controls. Finally, in column (4) we add the distance to the nearest seaport (Vancouver or Thunder Bay), which controls for the malt barley export basis. The point estimate 
for maltplant_dist remains stable as control variables are added and is statistically significant at the $1 \%$ level after adding the full set of controls. The regression coefficient for maltplant_dist in column (4) suggests that every $100 \mathrm{~km}$ increase in distance from a malt barley plant decreased malt barley production by $11 \%$ after the removal of the CWB. Using our example of two RMs located 50 and $150 \mathrm{~km}$ from the nearest malt barley plant, our point estimates suggest that malt barley acreage increased by $11 \%$ in the closer RM, following deregulation.

After adding all control variables, we observe that the removal of the CWB led to growth in malt barley production in RMs with drier August weather, which suggests that barley acreage shifted to areas with a natural comparative advantage. We also find that there was an overall increase in malt barley acreage in Alberta compared to Saskatchewan, although this effect loses significance once weather controls are added. After controlling for weather and province-specific trends, we find no evidence suggesting that RMs in areas further from seaport (and a higher export basis) appear to have decreased their production of malt barley after the CWB removal.

\section{Robustness}

We now check whether our main results are robust to including additional control variables, and the results are presented in Table 3. In column (1) we add a control for the number of pigs and cattle per acre in each RM, using data from the 2006 Census of Agriculture. These variables capture localized demand for feed barley. The results suggest that hog production has a negative and statistically significant impact on the production of malt barley, but we find no effect associated with cattle production. In column (2) we add a control for average January temperature, which can affect cattle production and hence local demand for feed barley, and we find no effects. Across columns (1) and (2) of Table 3 the maltplant_dist coefficient remains robust to including these additional controls. In column (3) we adjust our main variable of interest, to include nearby U.S. malting plants when calculating each RM's distance to its closest plant (maltplantUSdist), and we find that this augmented measure is also statistically significant with a similarly sized point estimate.

Finally, in column (4) of Table 3 we use Census Division Fixed Effects instead of province fixed effects. Census divisions are geographic regions larger than RMs, and there are 53 Census Divisions in our data. Census Division fixed effects in the first-differenced specification control for any unobserved changes in growing conditions at the regional level that affect acreage 
planted to malt barley varieties, including any unobserved weather and crop disease conditions (such as fusarium, a fungus). Including Census Division fixed effects means that the point estimates for maltplant_dist are driven by the variation in malt barley acreage within each Census Division over time. Even using this demanding specification, we find that our estimate for maltplant_dist is statistically significant at the 5\% level and the point estimate is even larger, suggesting that that every $100 \mathrm{~km}$ increase in distance from a malt barley plant decreased malt barley production by $21 \%$ after the deregulation.

In Table 4 we present the results using alternative dependent variables. In column (1) we use the change in logged production of barley (in tonnes) instead of acreage, and we find a negative and statistically significant effect of distance to the nearest malt barley plant. In column (2) we perform a placebo test, where we use the change in logged feed barley acreage as the dependent variable. The removal of the CWB monopoly did not directly affect feed barley marketing, but feed barley acreage may be positively related to distance to the nearest malt barley plant if malt barley production displaces feed barley in RMs closer to malt barley plants (and vice versa in RMs further from malt barley plants). We thus expect to find a positive impact of maltplant_dist on feed barley acreage. The results suggest that changes in feed barley acreage was positively affected by distance to malt plants before versus after the removal of the CWB single desk, which suggests that malt barley production displaced feed barley production in RMs closer to malt barley plants. Finding the opposite effect on feed barley means that we have more confidence that our results for malt barley are not spuriously driven by other factors that encouraged barley production of all kinds. Finally, in column (3) we generate a measure of malt barley production intensity, dividing malt barley acreage by total area in crops and summerfallow in each RM. The point estimate on maltplant_dist remains statistically significant using this alternative measure as well. It is also worth noting that the Alberta indicator is statistically significant across all columns of Table 3 and suggests that malt barley production and cropping intensity increased and feed barley decreased in Alberta relative to Saskatchewan during the 2008-2016 time period, independent of the distance to malt plants.

Finally, in order to check whether the statistical significance of our results changes if we account for spatial correlation in the error terms we use Conley (1999) standard errors in our main specification. The results are reported in Table 5, where we implement a 100km distance cutoff, which provides the most conservative standard errors. Comparing column (4) in Tables 1 
and 5 reveals that allowing for spatial correlation instead of clustering at the Census Division level results in very similar standard errors for maltplant_dist, and statistical significance remains at the $1 \%$ level. Overall, or results are robust to a wide variety of specifications.

\section{Conclusion}

The removal of the Canadian Wheat Board (CWB) marketing authority in 2012 provides a unique opportunity to measure the impact of that policy reform on the production of malt barley in Western Canada. We posit that the removal of the CWB monopoly-monopsony provided efficiency gains, particularly for growers located relatively close to malt barley plants and/or adept at consistently producing high quality malting barley. They were now free to enter into forward pricing and delivery contracts with malt barley plants. We also posit that transportation costs may have discouraged malt barley production by growers further away from malt plants, after removal of the CWB pooling. The decrease in marketing uncertainty in meeting quality criteria, conditional on managerial skill, meant that marginal growers were now less willing to produce malt barley varieties.

In accordance with our hypothesis, the results suggest that malt barley production shifted closer to malt barley plants. Our finding that single desk deregulation leads to a greater geographic specialization in the production of malt barley relates directly to the Ricardian concept that free trade allows regions to specialize according to comparative advantage, and agrees with empirical evidence in other studies. Overall, our results suggest that there were winners and losers from the ending of the CWB single desk authority, but the shift in production appears to reflect underlying comparative advantage in climate and proximity to downstream processing. 


\section{References}

Anderson, K,, M. Kurzweil, W. Martin, D. Sandri, and E. Valenzuela (2008). "Measuring Distortions to Agricultural Incentives, Revisited." World Trade Review 7, 675-704.

Canadian Wheat Board (CWB) (2012). Annual Report - Financial Results. Winnipeg, Canada.

Carter, C.A., R.M.A. Loyns, and D. Berwald (1998) "Domestic costs of statutory marketing authorities: the case of the Canadian Wheat Board." American Journal of Agricultural Economics 80, 313-24.

Conley, T. G. (1999). “GMM Estimation with Cross-Sectional Dependence," Journal of Econometrics 92(1):1-45.

Coşar, A. K. and P. D. Fajgelbaum (2016). "Internal geography, international trade, and regional specialization.” American Economic Journal: Microeconomics 8, 24-56.

Costinot, A and D. Donaldson (2016). "How Large Are the Gains from Economic Integration? Theory and Evidence from U.S. Agriculture, 1880-1997." NBER Working Paper 22946.

Donaldson, D. (2015) "Railroads of the Raj: Estimating the Impact of Transportation Infrastructure." American Economic Review, forthcoming.

Donaldson, D. and R. Hornbeck (2016) "Railroads and American Economic Growth. A 'Market Access' Approach.” Quarterly Journal of Economics 131, 799-858.

Fajgelbaum, P., and S. Redding (2014): "External Integration and Internal Development: Evidence from Argentina, 1870-1914," NBER Working Paper 20217.

Hoekman, B. and J.P. Trachtman (2008) "Canada-Wheat: Discrimination, non-commercial Considerations, and the right to regulate through State Trading Enterprises." World Trade Review. 7, 45-66.

Harris, I. P. D. J., P. D. Jones, T. J. Osborn, and D. H. Lister (2014). Updated high-resolution grids of monthly climatic observations-the CRU TS3. 10 Dataset. International Journal of Climatology, 34(3), 623-642.

Hsieh, C., and P. Klenow (2009) "Misallocation and manufacturing TFP in China and India." Quarterly Journal of Economics 124, 1403-1448.

McCorriston, S., and D. MacLaren (2007) "Deregulation as (welfare reducing) trade reform: the case of the Australian Wheat Board." American Journal of Agricultural Economics 89, 637-50.

McCorriston, S., and D. MacLaren (2013) "Redistribution, state trading enterprises and 'politically optimal' tariffs." Canadian Journal of Economics 46, 1351-1379. 
Peterson, E., and S. Valluru (2000). "Agricultural comparative advantage and government policy interventions." Journal of Agricultural Economics 51.3 (2000): 371-387.

Sotelo, S. (2016). “Domestic trade frictions and agriculture.” In W. Schlenker (Ed.)

Understanding Productivity Growth in Agriculture, NBER Conference Volume, Forthcoming.

Horlick, G. N. and K. H. Mowry (1998) "The Treatment of Activities of State Trading

Enterprises under the WTO Subsidies Rules", in T. Cottier and P. C. Mavroidis (eds), State

Trading in the Twenty-First Century, Ann Arbor, Michigan: University of Michigan Press, pp. 97-114.

Wilson, W. W. (2009) "Crop Insurance in Malting Barley: A Stochastic Dominance Analysis." Agrifinance Review 69, 98-112. 


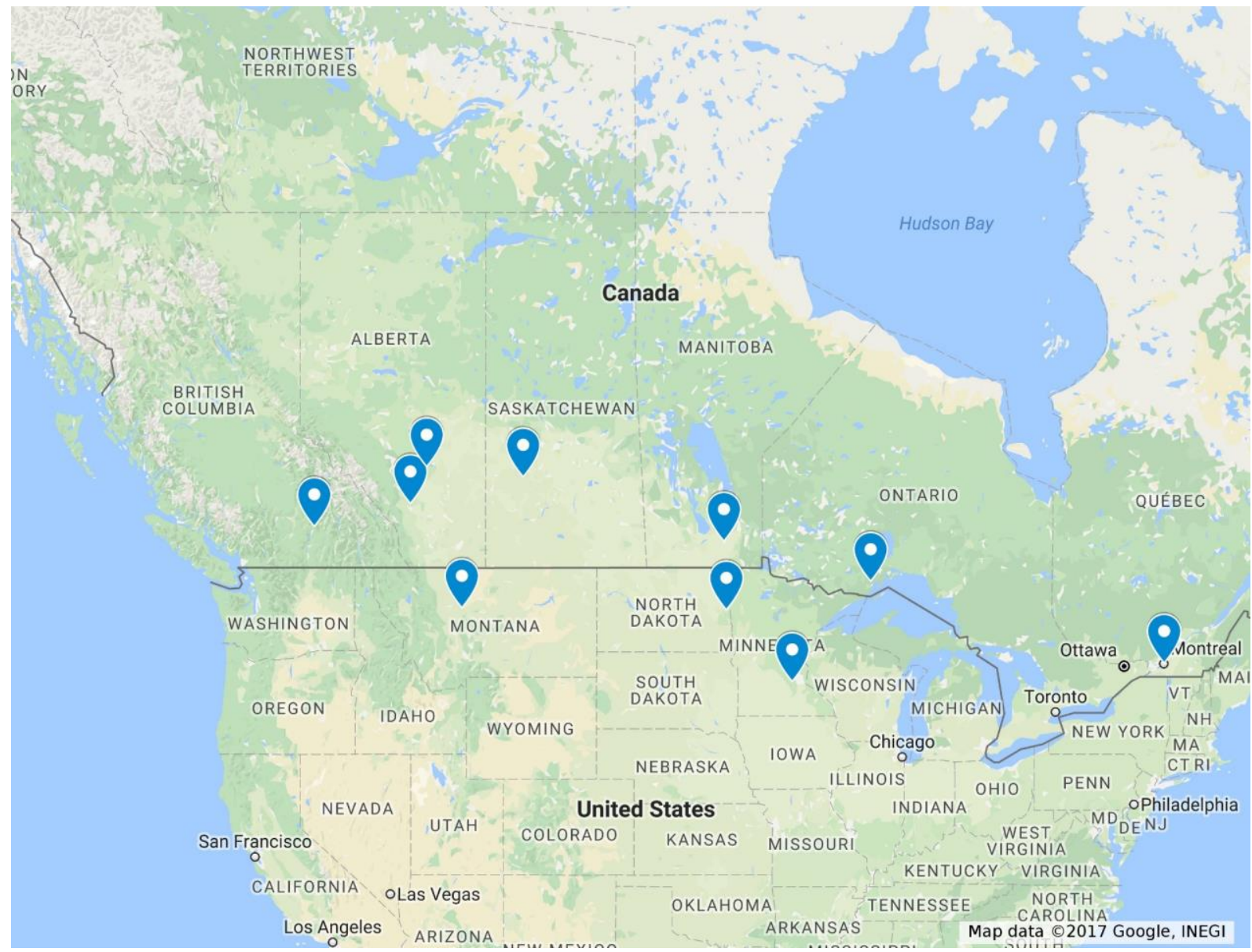

Figure 1: Location of malt barley plants in Canada and Northern U.S. Great Plains Source: Google Maps, authors' calculations. 


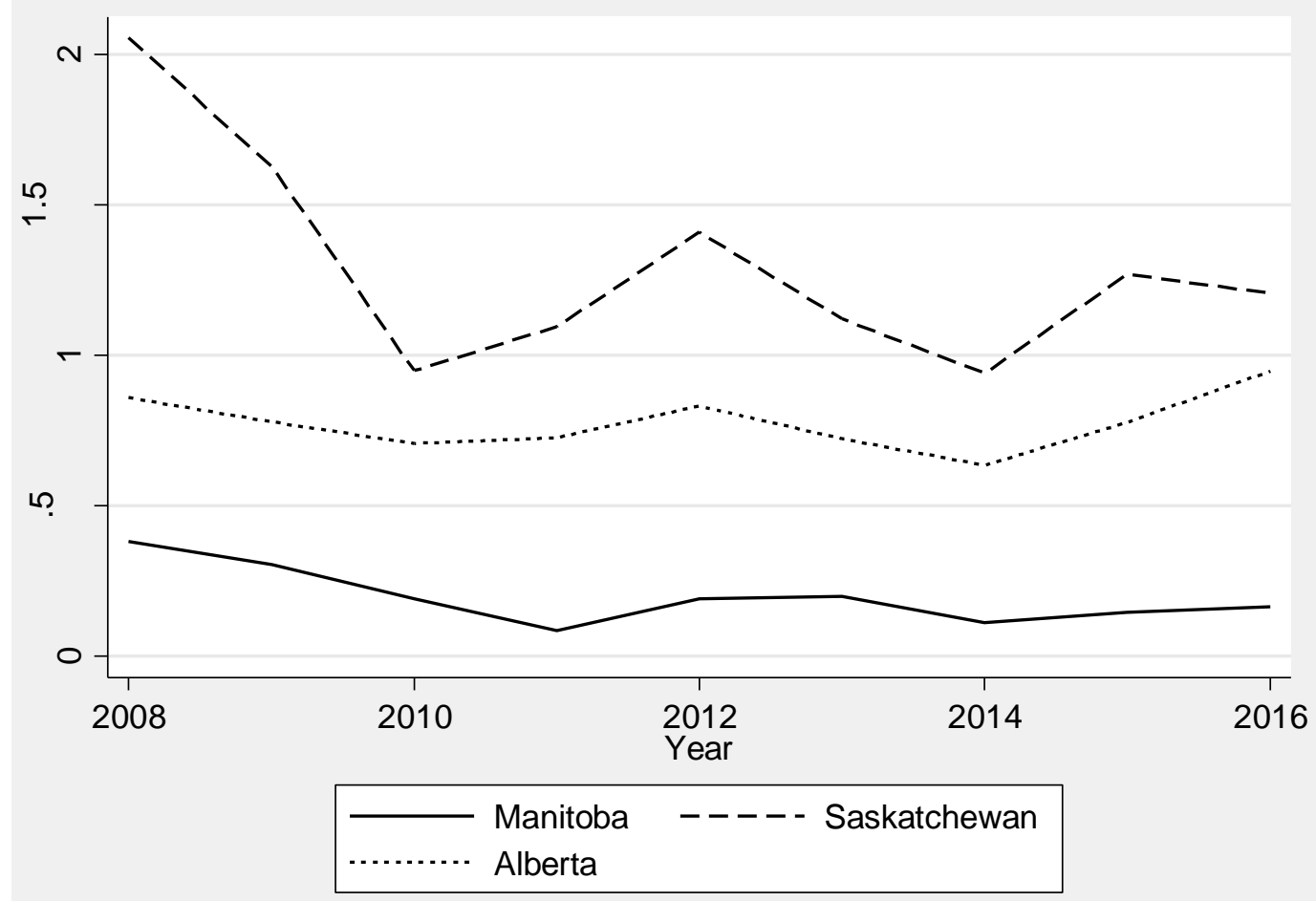

Figure 2: Insured malt barley acreage by province, million acres. Source: MASC, SCIC, AFSC 


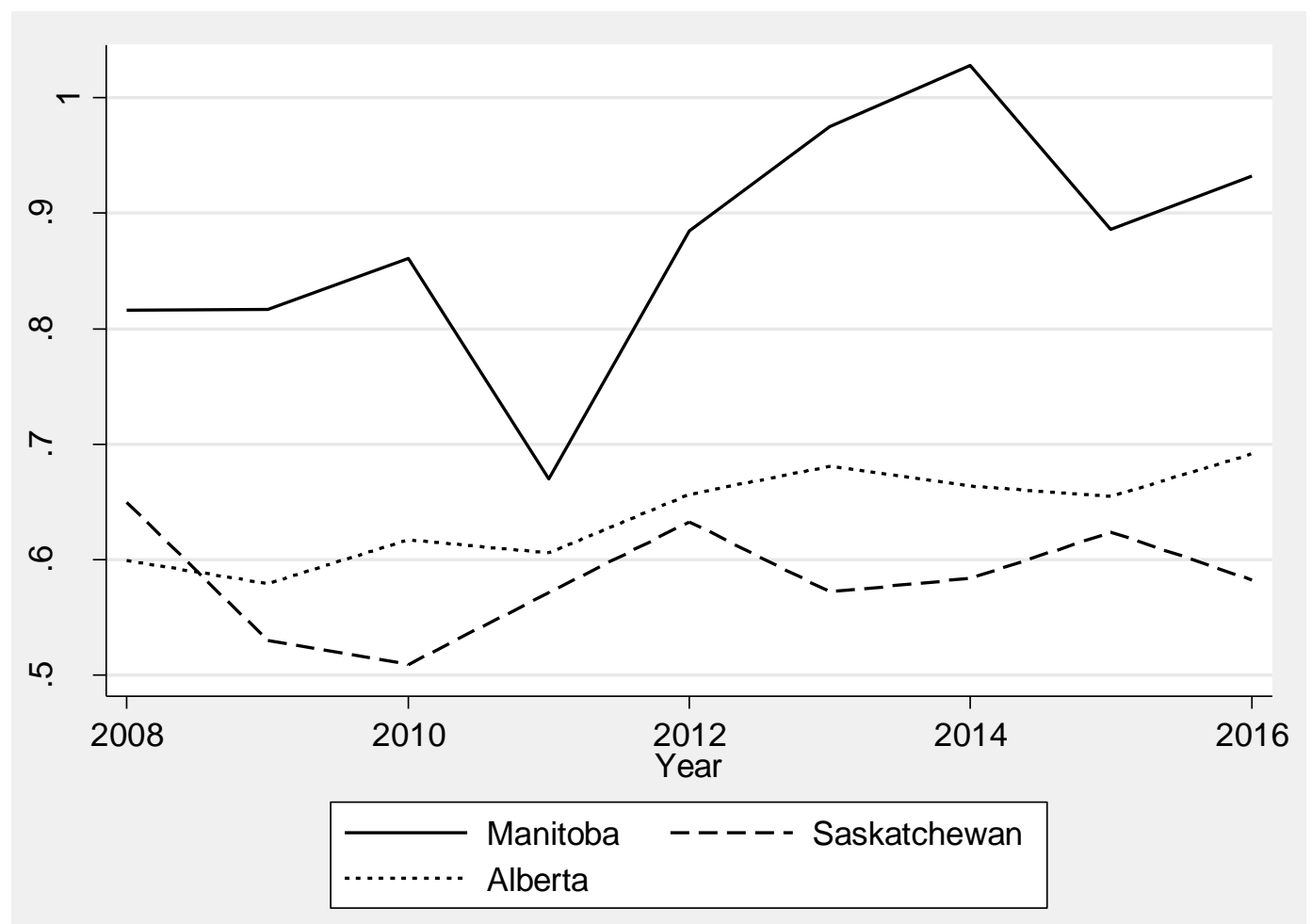

Figure 3: Share of barley acres insured by crop insurance by province. Source: MASC, SCIC, AFSC, Statistics Canada 


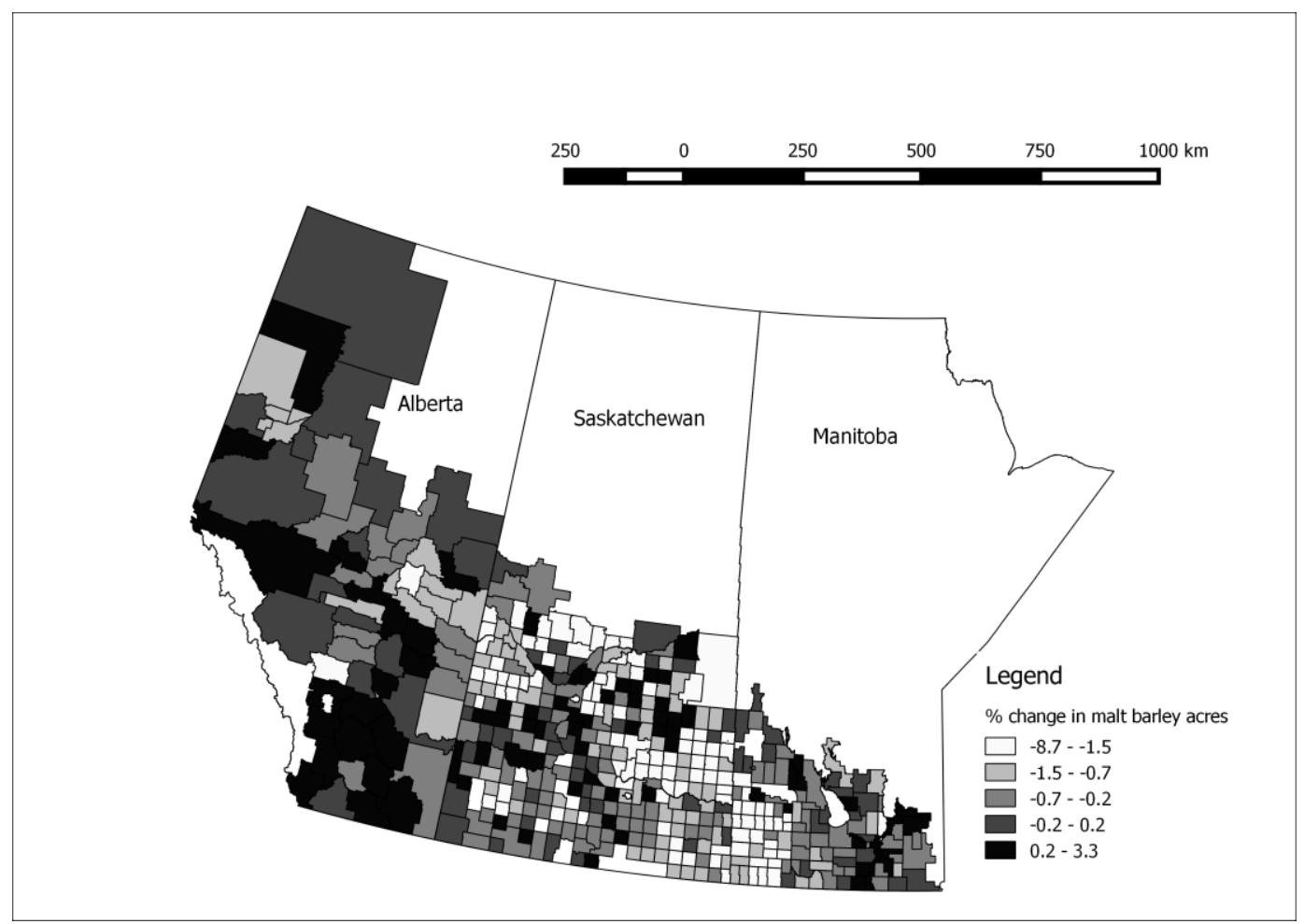

Figure 4: Percentage change in malt barley acres between 2008-11 and 2013-16 for Alberta, Saskatchewan and Manitoba.

Source: MASC, SCIC, AFSC, Authors calculations 
Table 1: Malt Barley Supply and Disposition, Western Canada (Alberta, Saskatchewan and Manitoba)

\begin{tabular}{|c|c|c|c|c|c|c|c|c|c|c|}
\hline & & $2007 / 08$ & $2008 / 09$ & $2009 / 10$ & $2010 / 11$ & $2011 / 12$ & $2012 / 13$ & $2013 / 14$ & $2014 / 15$ & $2015 / 16$ \\
\hline & & \multicolumn{9}{|c|}{ Thousand Tonnes } \\
\hline \multirow[t]{2}{*}{$\begin{array}{l}\text { Participation- } \\
\text { adjusted: }\end{array}$} & $\begin{array}{l}\text { Production of malt } \\
\text { varieties }\end{array}$ & 5207 & 6208 & 5520 & 3365 & 3663 & 3692 & 4773 & 3028 & 3887 \\
\hline & Selection rate & 0.49 & 0.40 & 0.42 & 0.44 & 0.50 & 0.45 & 0.44 & 0.54 & 0.44 \\
\hline \multirow[t]{2}{*}{ Unadjusted: } & $\begin{array}{l}\text { Production of malt } \\
\text { varieties }\end{array}$ & 3630 & 4700 & 3747 & 2218 & 2580 & 2669 & 3350 & 2166 & 3165 \\
\hline & Selection rate & 0.70 & 0.52 & 0.61 & 0.67 & 0.70 & 0.62 & 0.63 & 0.76 & 0.54 \\
\hline \multirow[t]{2}{*}{ Supply: } & Selected (imputed) & 2536 & 2462 & 2302 & 1481 & 1815 & 1656 & 2117 & 1643 & 1703 \\
\hline & Imports & 49 & 38 & 33 & 40 & 15 & 8 & 9 & 69 & 40 \\
\hline \multirow[t]{3}{*}{ Disposition: } & Exports & 1300 & 1300 & 1200 & 400 & 700 & 600 & 1000 & 600 & 600 \\
\hline & $\begin{array}{l}\text { Brewers and } \\
\text { Distillers Use }\end{array}$ & 375 & 375 & 375 & 375 & 375 & 375 & 375 & 375 & 375 \\
\hline & $\begin{array}{l}\text { Malt Exports (bly } \\
\text { equivalent) }\end{array}$ & 910 & 825 & 761 & 746 & 756 & 689 & 751 & 736 & 768 \\
\hline
\end{tabular}

Notes: Participation-adjusted production adjusted upward to account for uninsured acres (using Statistics Canada annual survey data on total barley crop). Unadjusted production uses the raw crop insurance data. Malt barley import data taken from USDA. Malt barley export data derived from IGC Grain Market Reports. Malt export data taken from World Trade Atlas. Brewers and Distillers Use assumed to be 375 thousand tonnes (personal communication with Phil DeKamp, May 1, 2017). Malt exports and Brewers and Distillers Use are multiplied by a factor of 1.25 to report in raw barley equivalents. The imputed selected malt barley is determined by summing exports, brewers and distillers use and malt exports. The selection rate is the ratio of production to selected malt barley. All values based on crop year (August $1^{\text {st }}-\mathrm{July} 31^{\text {st }}$ ). Sources: International Grains Council, (various years), Statistics Canada, World Trade Atlas, authors calculations. 
Table 2: Main Results

\begin{tabular}{|c|c|c|c|c|}
\hline \multirow{3}{*}{ Dep. var.: } & \multicolumn{4}{|c|}{ First-Difference, 2008-2011 avg. vs. 2012-2016 avg. } \\
\hline & \multicolumn{4}{|c|}{$\Delta \ln (\text { maltbarleyacres })_{i, 08-16}$} \\
\hline & $(1)$ & $(2)$ & (3) & $(4)$ \\
\hline \multirow{2}{*}{ Amaltplant_dist $t_{i, 08-16}$} & $-0.00105 * * *$ & $-0.00104 * * *$ & $-0.00116^{* * *}$ & $-0.00112 * * *$ \\
\hline & $(0.000261)$ & $(0.000249)$ & $(0.000347)$ & $(0.000335)$ \\
\hline \multirow[t]{2}{*}{$M B_{i}$} & & 0.0187 & 0.178 & 0.113 \\
\hline & & $(0.0882)$ & $(0.116)$ & $(0.159)$ \\
\hline \multirow[t]{2}{*}{$A B_{i}$} & & $0.147 *$ & $0.276^{* *}$ & 0.219 \\
\hline & & $(0.0853)$ & $(0.133)$ & $(0.177)$ \\
\hline \multirow[t]{2}{*}{$\Delta j u l y \_t e m p_{i, 07-15}$} & & & -0.130 & -0.141 \\
\hline & & & $(0.0804)$ & $(0.0884)$ \\
\hline \multirow[t]{2}{*}{$\Delta a u g \_$precip $p_{i, 07-15}$} & & & $-0.00520 *$ & $-0.00514^{*}$ \\
\hline & & & $(0.00280)$ & $(0.00283)$ \\
\hline \multirow[t]{2}{*}{ portmindist $_{i}$} & & & & -0.000194 \\
\hline & & & & $(0.000350)$ \\
\hline \multirow[t]{2}{*}{ Constant } & -0.0818 & -0.110 & -0.117 & 0.0870 \\
\hline & $(0.0719)$ & $(0.0818)$ & $(0.0974)$ & $(0.392)$ \\
\hline Observations & 420 & 420 & 417 & 417 \\
\hline R-squared & 0.046 & 0.054 & 0.065 & 0.066 \\
\hline
\end{tabular}

Notes: Robust standard errors in parentheses, clustered at Census Division Level $* * * p<0.01, * *$ $\mathrm{p}<0.05, * \mathrm{p}<0.1$ 
Table 3: Robustness to additional controls

\begin{tabular}{|c|c|c|c|c|}
\hline \multirow{3}{*}{ Dep. var.: } & \multicolumn{4}{|c|}{ First-Difference, 2008-2011 avg. vs. 2012-2016 avg. } \\
\hline & \multicolumn{4}{|c|}{$\Delta \ln (\text { maltbarleyacres })_{i, 08-16}$} \\
\hline & (1) & $(2)$ & $(3)$ & $(4)$ \\
\hline Amaltplant_dist $t_{i, 08-16}$ & $-0.00119 * * *$ & $-0.00118 * * *$ & & $-0.00209 * *$ \\
\hline & $(0.000347)$ & $(0.000323)$ & & $(0.000811)$ \\
\hline$M B_{i}$ & 0.123 & 0.0812 & 0.115 & \\
\hline & $(0.160)$ & $(0.171)$ & $(0.159)$ & \\
\hline$A B_{i}$ & 0.242 & 0.258 & 0.223 & \\
\hline & $(0.190)$ & $(0.182)$ & $(0.177)$ & \\
\hline$\Delta j u l y \_t e m p_{i, 07-15}$ & -0.145 & -0.156 & -0.134 & $-0.302 * *$ \\
\hline & $(0.0878)$ & $(0.0946)$ & $(0.0904)$ & $(0.117)$ \\
\hline$\Delta a u g \_p r e c i p i_{i, 07-15}$ & $-0.00567 *$ & $-0.00580 * *$ & $-0.00517 *$ & -0.00180 \\
\hline & $(0.00296)$ & $(0.00283)$ & $(0.00280)$ & $(0.00422)$ \\
\hline portmindist $_{i}$ & -0.000271 & -0.000260 & -0.000180 & -0.000441 \\
\hline & $(0.000365)$ & $(0.000372)$ & $(0.000350)$ & $(0.00107)$ \\
\hline Pigs $_{i .06}$ & $\begin{array}{c}-0.0525 * * * \\
(0.0146)\end{array}$ & & & \\
\hline cattle $_{i .06}$ & $\begin{array}{l}-0.177 \\
(0.432)\end{array}$ & & & \\
\hline$j a n \_t e m p \_a v g_{i}$ & & $\begin{array}{l}-0.0146 \\
(0.0173)\end{array}$ & & \\
\hline Amaltplant USdist $t_{i, 08-16}$ & & & $\begin{array}{c}-0.00115^{* * *} \\
(0.000337)\end{array}$ & \\
\hline Constant & $\begin{array}{c}0.198 \\
(0.420)\end{array}$ & $\begin{array}{l}-0.0747 \\
(0.422)\end{array}$ & $\begin{array}{l}0.0782 \\
(0.391)\end{array}$ & $\begin{array}{l}1.117 * \\
(0.606)\end{array}$ \\
\hline $\begin{array}{l}\text { Census Division } \\
\text { Fixed Effects }\end{array}$ & NO & NO & NO & YES \\
\hline Observations & 417 & 416 & 417 & 417 \\
\hline R-squared & 0.072 & 0.067 & 0.067 & 0.263 \\
\hline
\end{tabular}

Notes: Robust standard errors in parentheses, clustered at Census Division Level $* * * p<0.01$, $* * \mathrm{p}<0.05, * \mathrm{p}<0.1$ 
Table 4: Alternative dependent variables

\begin{tabular}{|c|c|c|c|}
\hline & \multicolumn{3}{|c|}{ First-Difference, 2008-2011 avg. vs. 2012-2016 avg. } \\
\hline Dep. var.: & $\begin{array}{c}\Delta \ln (\text { maltbarley } \\
\text { tonnes })_{i, 08-16}\end{array}$ & $\begin{array}{c}\Delta \ln (\text { feedbarley } \\
\text { acres })_{i, 08-16}\end{array}$ & $\begin{array}{c}\Delta \ln (\text { percentbarley } \\
\text { acres }_{i, 08-16}\end{array}$ \\
\hline Amaltplant_dist $t_{i, 08-16}$ & $\begin{array}{c}-0.00146 * * * \\
(0.000414)\end{array}$ & $\begin{array}{l}0.00114 * * \\
(0.000449)\end{array}$ & $\begin{array}{c}-0.00278 * * * \\
(0.000711)\end{array}$ \\
\hline$M B_{i}$ & $\begin{array}{l}0.0673 \\
(0.168)\end{array}$ & $\begin{array}{c}-0.497 * * * \\
(0.192)\end{array}$ & $\begin{array}{c}0.323 \\
(0.427)\end{array}$ \\
\hline$A B_{i}$ & $\begin{array}{c}0.403 * * \\
(0.174)\end{array}$ & $\begin{array}{c}-0.447 * * \\
(0.192)\end{array}$ & $\begin{array}{c}1.064 * * * \\
(0.368)\end{array}$ \\
\hline ujuly_temp ${ }_{i, 07-15}$ & $\begin{array}{c}-0.178 * * * \\
(0.0625)\end{array}$ & $\begin{array}{l}0.0245 \\
(0.127)\end{array}$ & $\begin{array}{l}-0.260^{*} \\
(0.137)\end{array}$ \\
\hline$\Delta a u g \_$precip $i, 07-15$ & $\begin{array}{c}-0.0119 * * * \\
(0.00280)\end{array}$ & $\begin{array}{c}0.00468 \\
(0.00475)\end{array}$ & $\begin{array}{c}-0.0220 * * * \\
(0.00628)\end{array}$ \\
\hline portmindist $_{i}$ & $\begin{array}{l}-0.000467 \\
(0.000362)\end{array}$ & $\begin{array}{l}-0.000213 \\
(0.000441)\end{array}$ & $\begin{array}{l}-0.000865 \\
(0.000925)\end{array}$ \\
\hline Constant & $\begin{array}{c}0.598 \\
(0.431)\end{array}$ & $\begin{array}{c}0.234 \\
(0.461)\end{array}$ & $\begin{array}{c}0.657 \\
(1.009)\end{array}$ \\
\hline $\begin{array}{l}\text { Observations } \\
\text { R-squared }\end{array}$ & $\begin{array}{c}417 \\
0.094\end{array}$ & $\begin{array}{c}376 \\
0.074\end{array}$ & $\begin{array}{c}435 \\
0.104\end{array}$ \\
\hline
\end{tabular}

Notes: Robust standard errors in parentheses, clustered at Census Division Level $* * * p<0.01$, ** $\mathrm{p}<0.05, * \mathrm{p}<0.1$ 
Table 4: Controlling for spatial correlation

\begin{tabular}{|c|c|c|c|c|}
\hline \multirow{3}{*}{ Dep. var.: } & \multicolumn{4}{|c|}{ First-Difference, 2008-2011 avg. vs. 2012-2016 avg. } \\
\hline & \multicolumn{4}{|c|}{$\Delta \ln (\text { maltbarleyacres })_{i, 08-16}$} \\
\hline & $(1)$ & $(2)$ & (3) & (4) \\
\hline \multirow{2}{*}{$\Delta m a l t p l a n t \_d i s t_{i, 08-16}$} & $-0.00105^{* * *}$ & $-0.00104 * * *$ & $-0.00116 * * *$ & $-0.00112 * * *$ \\
\hline & $(0.000274)$ & $(0.000298)$ & $(0.000371)$ & $(0.000339)$ \\
\hline \multirow[t]{2}{*}{$M B_{i}$} & & 0.0187 & 0.178 & 0.113 \\
\hline & & $(0.125)$ & $(0.168)$ & $(0.242)$ \\
\hline \multirow[t]{2}{*}{$A B_{i}$} & & 0.147 & 0.276 & 0.219 \\
\hline & & $(0.0943)$ & $(0.173)$ & $(0.213)$ \\
\hline \multirow[t]{2}{*}{ Sjuly_temp $_{i, 07-15}$} & & & -0.130 & -0.141 \\
\hline & & & $(0.0856)$ & $(0.0904)$ \\
\hline \multirow[t]{2}{*}{$\Delta a u g \_p r e c i p p_{i, 07-15}$} & & & -0.00520 & -0.00514 \\
\hline & & & $(0.00389)$ & (0.00389) \\
\hline \multirow[t]{2}{*}{ portmindist $_{i}$} & & & & -0.000194 \\
\hline & & & & $(0.000428)$ \\
\hline \multirow[t]{2}{*}{ Constant } & -0.0818 & -0.110 & -0.117 & 0.0870 \\
\hline & $(0.0846)$ & $(0.111)$ & $(0.112)$ & $(0.486)$ \\
\hline Observations & 420 & 420 & 417 & 417 \\
\hline R-squared & 0.258 & 0.264 & 0.271 & 0.272 \\
\hline
\end{tabular}

Notes: Robust standard errors in parentheses, using Conley (1999) standard errors with a 100km distance cutoff. $* * * \mathrm{p}<0.01, * * \mathrm{p}<0.05, * \mathrm{p}<0.1$ 